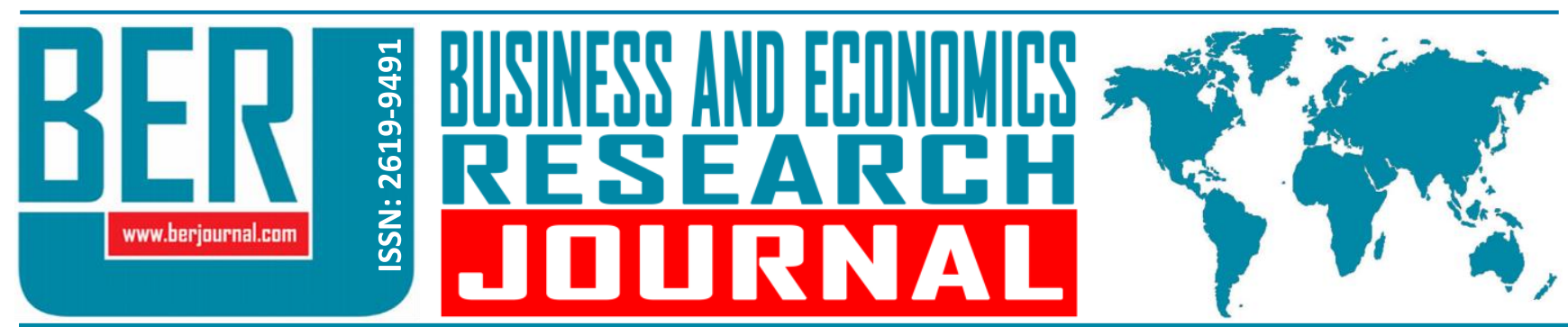

Business and Economics Research Journal Vol. 12, No.3, $2021 \quad$ pp. 491-507

doi: 10.20409/berj.2021.334

\title{
The Real Effective Exchange Rate and Industrial Employment: The Turkish Case
}

\author{
Resat Can Akkay ${ }^{\mathrm{a}}$
}

Abstract: This study investigates the relationship between industrial employment and producer price index-based real effective exchange rate, over the period 2009M01$2019 M 10$, by employing the autoregressive distributed lag cointegration procedure, for the Turkish economy. The empirical findings support the existence of a positive relationship between the appreciation of the producer price index-based real effective exchange rate and an increase in industrial employment. Accordingly, a 1\% appreciation of the producer price index-based real effective exchange rate leads to a $0.092 \%$ increase in industrial employment. This finding supports the dominance of the "imported input" channel over the other transmission channels for Turkey at the industry level.

Keywords: Real Effective Exchange Rate, Industrial Employment, ARDL Model, Aggregation Bias, Turkey

JEL: E24, F31, C22

$\begin{array}{ll}\text { Received } & : 15 \text { March } 2021 \\ \text { Revised } & : 26 \text { May } 2021 \\ \text { Accepted } & : 08 \text { July } 2021\end{array}$

Type : Research

\section{Introduction}

The relationship between employment level and the real exchange rate (henceforth REER) changes may be dated back to the end of the Bretton Woods System. The unsatisfactory experiences of the goldexchange standard of the Interwar period (1914-1939) and the broken link between gold reserves and the U.S. (the United States) dollars in the Bretton Woods system raised the attention to the optimal exchange rate system which was expected to remove the external imbalances (Bordo, 1993). The growing volume of international trade after the 1980s increased the debate about the choice of the exchange rate system which is supposed to improve international trade and hinder the potential adverse impacts of the capital outflows. Many emerging market countries experienced currency crises over this period and it has been proved several times that the impossible trinity is not just a hypothesis but also a real fact. ${ }^{1}$ As a result, almost all emerging market countries started to use different versions of the floating exchange rate system with good or bad grace. China, for example, as the biggest emerging market country has been using managed floating exchange rate system for years which aims to the undervaluation of the Yuan against the reserve currencies like the U.S. dollar and the Euro. The impressive economic performance of China in the last two decades can be taken as proof of the effectiveness of the exchange rate policy as one of the primary trade policy tools. In short, one can conclude that the competitive exchange rates have been playing an important role in the economic performance of the countries since the beginning of the trade liberalization of the 1980s. This observation led many researchers to explore the impact of the exchange rate movements from different perspectives like its relationship with economic growth, inflation rate, trade balance, or labor market.

a Asst. Prof., PhD., Istanbul University, Faculty of Economics, Department of Economics, Istanbul, Turkiye, canakkay@istanbul.edu.tr (ORCID ID: 0000-0002-1005-5828) 
The theoretical background of the labor market literature depends on some transmission channels which are suggested by different researchers to explain the way how the exchange rate changes may affect the employment levels or unemployment rates. The "macroeconomic", "labor-intensity", and "development" channels (Frenkel \& Ros, 2006); the "technology", "export volume", and "efficiency improvement" channels (Hua, 2007); and the "macro" and "micro" channels (Ngandu, 2008) are the mostknown mechanisms in the literature. These channels provide a basic understanding of the relationship and guide the researchers about their approach to the empirical investigation. Besides, the relative importance and strength of these channels among countries can be another field of research since countries have different economic characteristics and economic structures.

The detailed survey of the literature indicates that the change in REER is employed as the independent variable in all empirical studies as a common feature. Besides, it is observed that both employment level and unemployment rate are used as the dependent variables to represent the developments in the labor market. Furthermore, the studies can be classified as studies at aggregate and at disaggregate levels.

The literature review shows that some shortcomings should be underlined. The first one is about the aggregation bias. Some studies explore this relationship at a country level and do not mention the varying responses of different sectors to the exchange rate changes at the sectoral level due to the structural differences like being more labor-intensive, capital-intensive, or being more open to international trade. In short, the aggregation bias may cause spurious results about the relationship since the positive and negative responses of different sectors may cancel each other. The second shortcoming is about the usage of the unemployment rate as the proxy for the labor market reactions to the exchange rate changes. The unemployment rate is an indirect measure that is affected also by the labor force participation rate. It means that the "not in the labor force" group and their reaction to the exchange rate changes should be also added into the analysis.

This paper aims to investigate the impact of the exchange rate changes on the Turkish labor market by considering the mentioned two shortcomings. In the light of the criticism above, the producer price index based-REER (henceforth REER-PPI) and the industrial employment level (henceforth I-EMP) are employed as the two consistent proxies for the investigation of the exchange rate-labor market relationship. The research period is 2009-2019 and the data frequency is monthly. The choice about the period helped us to avoid the destructive effects of the Great Recession while the monthly frequency allows us to determine the response of the employment level to the REER changes more realistically relative to the studies which employ yearly or quarterly data. In addition to the monthly data usage, which is rarely preferred in the literature, we added two new control variables to our model; (i) banking credits to the private sector and (ii) foreign direct investments. These two new variables allow us to construct an empirical model that reflects the countryspecific facts of the Turkish economy.

The plan of the study is as follows. The literature review can be found in the next section which is summarized also in Table 1. In the third section, the empirical relationship between REER-PPI and I-EMP is investigated for the short run and the long run by employing the ARDL (autoregressive distributed lag) procedure. In the last section, the empirical results are compared with the findings of the other studies, and some discussions are made for future studies.

\section{Literature Review}

Mundell's investigation is one of the pioneering theoretical studies that led up the literature about REER and employment. Mundell (1961) concludes that the depreciation of the domestic currency as a commercial policy tool is not as effective as the expansionary monetary and fiscal policies over the employment level under the flexible exchange rate system. Branson and Love (1988) find out empirically that the changes in REER affect the employment level significantly by increasing the competitiveness in international trade because of the decrease in the relative product prices. They also determine that the negative effect of currency appreciation over employment is visible especially in the durable goods sectors 
like stone, metal, electrical machinery, textile, and apparel. Glick and Hutchinson (1990) state that dollar appreciation in the U.S. has an unstable, sample-specific effect on sectoral output and employment. Revenga (1992) shows that the exchange rate fluctuations have real economic effects like the decrease in employment in the trade-affected industries during the depreciation of the U.S. dollar. Burgess and Knetter (1998) compute the exchange rate elasticities of 30 industries in G-7 countries. The empirical findings show that employment is less sensitive to the exchange rate shocks in Japan and Germany relative to other G-7 countries. They stress the market structures and the international trade regulations as two primary sources for the differences among countries. Dekle (1998) shows a significant relationship between the changes in REER and manufacturing employment in Japan in the long run. He also concludes that the higher is the competitiveness of the industry, the greater will be the response of the employment to the changes in REER. On the other hand, there is no significant difference between the response of the high-tech and low-tech export sectors. Gourinchas (1999) examines the real exchange rate-employment relationship for France by using firm-level data. According to their results, $1 \%$ appreciation of the REER affects the tradable jobs negatively by $0,95 \%$ over the next two years. Campa and Goldberg (2001) examine the relationship between REER and employment in specific U.S. manufacturing industries. They state that the employment in the low mark-up industries and industries with a less skilled workforce is more responsive to the REER changes while industries with more educated workers indicate lower employment elasticities. Kandil and Mirzaie (2003) observe that the appreciation of the dollar harms the labor market at the aggregate level but the findings at the sectoral level are controversial. The negative effect of the appreciation is significant in the construction sector while the same appreciation has a positive effect on the labor growth in the mining sector. As far as we know the first study about Turkey was done by Filiztekin (2004). The author underlines the high share of the imported inputs in industrial production as a problem that causes a positive relationship between exchange rate depreciation and employment decreases. The empirical results show that a $10 \%$ depreciation of the Turkish lira causes a $1.6 \%$ decline in manufacturing employment. The author also states that the response of the employment to the exchange rate changes differs from industry to industry, and the most affected sector is the clothing sector in the Turkish economy. Bilgin and Danis (2005) indicate a positive relationship between the employment level and the appreciation of the REER in the long run. They underline that there is no consensus about the sign and strength of the relationship and it may differ from sector to sector and from country to country. Likewise, Faria and Leon-Ladesma (2005) state that appreciation affects the employment level negatively in the US but positively in the UK. Frenkel and Ros (2006) brought a new dimension to the literature with their two contributions. The first contribution is about employing the unemployment rate instead of the employment level. The second and more important contribution is about the introduction of three transmission channels through exchange rate changes that affect the unemployment level. The first one is called the "macroeconomic channel" and takes its roots from the traditional Keynesian approach. Accordingly, the depreciated currency increases the net exports, and the firms in the tradable sectors can create more jobs. More jobs mean an increase in the demand for goods and services which are produced for the domestic market which in turn decreases the unemployment level even further. The second channel is called the "labor intensity channel" and is about the cost advantage that arises from the decreases in real wages due to the depreciation of the domestic currency. This increase in competitiveness creates more jobs for the tradable sector. The "development channel", the third and last one, is about the increasing competitiveness of the exportable goods since the depreciated currency acts as a tariff on imports and a subsidy on exports which creates more jobs. The empirical results show that the appreciation of REER and the unemployment rate have a significant and positive relationship based on the empirical investigation of 17 Latin American countries. Besides the important theoretical contribution of the study, the approach about the usage of the "unemployment rate" as the dependent variable empirically is followed only by few studies. (Boz 2013, Nyahokwe 2013, Bakshi \& Ebrahimi 2016, Usman \& Elsalih 2018, Akarsu 2020). Bahmani-Oskooee (2007) examines the relationship in eight major sectors. The empirical investigation shows that the depreciation of the dollar affects employment and wages in the short run. In contrast, this impact disappears in the long run regardless of the sector. Hua (2007) introduces three transmission channels by following the study of Frenkel and Ros (2006). The "export volume" channel is about the negative impact of the appreciation of REER over the tradable goods sectors by increasing the relative 
prices of the exportable goods which affect employment negatively. This channel is similar to the "development channel" of Frenkel and Rose (2006) but the other two channels, "technology" and "efficiency improvement" channels bring a new perspective to the transmission channels. The "technology channel" is about the transition of the production process from the labor-intensive methods to the imported technologybased methods due to the appreciation of the REER which may cause a decrease in employment. The "efficiency improvement" channel, on the other hand, is about the increased efficiency of the labor due to the appreciation of the REER. According to this approach, the increase in the purchasing power of the workers through exchange rate appreciation leads to an increase in work motivation and efficiency which decreases the need for new employment. His findings show that the real revaluation of the Yuan has a significant negative effect on Chinese manufacturing employment mostly through the "technology channel". Ngandu (2008) examines the transmission channels at the macro and micro levels. The author defines three macro channels as the "developmental, macroeconomic, and factor intensity" channels which are previously suggested by Frenkel and Ros (2006) and Hua (2007). The contribution of Ngandu (2008) is about the introduction of five new transmission channels that establish a relationship between employment and REER at the sectoral level. The "export orientation channel" is based on the idea that industries with greater export shares will show higher sensitivity to the changes in the exchange rates relative to the industries that produce only for the domestic market. The depreciation of the REER is expected to affect industrial employment positively in these sectors. The "imported input channel" is about industries with a heavy dependency on imported inputs. The appreciation of the REER affects these industries positively by decreasing the relative input prices which increases the production, profits, and employment. The "import penetration channel" is about the effect of the changes in REER on the industries which are open to significant foreign competition. The appreciation of the real exchange increases the demand for relatively cheap foreign goods and decreases demand for domestic substitutes which causes a decrease in sectoral employment. The "market structure" and "labor market regulation" channels focus on the market and regulatory forces that can affect the REERemployment relationship. The competitive market structure is more responsive to the changes in REER. Labor regulations, which make hiring and firing workers harder, decrease the negative impact of the REER on the employment level. The empirical investigation indicates that the appreciation of the dollar harms employment in the manufacturing sector in South Africa. The author concludes that the response of the employment level may differ from sector to sector. The aggregate response might be positive, negative, or neutral as the sum of all the responses of different sectors. Demir (2010) finds out that the volatility of REER has a significant negative effect on employment growth, especially in export-intensive firms. An increase in the REER volatility by one standard deviation decreases employment growth by 1.4 to 2.1 percentage points. Dao and Chen (2011) show that the appreciation of the REER has a strong negative effect on employment in both tradable and non-tradable sectors. They also state that the services sector which is more connected with tradable sectors faces a stronger contraction in employment following an appreciation of the REER. Alexandre (2011) states that the effect of the changes in REER on employment is relatively low in sectors that use high technology while this effect is evident in low technology sectors subject to foreign trade. Sahin and Cengiz (2011) show a cointegration between REER and employment level but the cointegration is not valid for some sectors like mining and finance. Xiangquan et al. (2011) find out that a competitive and stable exchange rate is crucial for the creation of employment. The volatility harms employment both in the short run and in the long run. Mpofu (2013) shows that the volatility in REER has a significant counteracting effect on manufacturing employment growth both in the short- and in the long run. The research also shows that depreciation of the domestic currency and the decrease of the volatility in REER have a positive effect on the employment level. Huang et al. (2014) state that a 1 percent increase in the REER decreases the employment in the manufacturing sector by 0.66 percent while there is no such a relationship in other sectors. Zmami and Ben Salha (2015) finds out that the depreciation of the effective exchange rate and bilateral exchange rate vis-à-vis the Euro and the US dollar affects employment positively in different sectors. The exchange rate elasticity of employment differs among firms according to the industry, ownership structure, and trade openness. Peláez S. and Sierra S. (2016) determine similar results with the findings of Zmami and Ben Salha (2015). The appreciation of the real exchange rate decreases the employment in the manufacturing sector but the results show differences among the sub-sectors. Employment in seven of the manufacturing 
industries indicates a positive response to the real appreciation while 18 of them show a negative response. Ay and Ayhan (2016) state the negative impact of the exchange rate volatility on the employment level. Alexandre (2017) finds out that the market rigidity decreases the exchange rate elasticity of employment in different industries. The rigidity is lower in low- and medium-low-technology sectors. Chipeta et al. (2017) show that the depreciation of REER affects overall employment negatively. Dogan and Islam (2018) find a positive relationship between the changes in REER and manufacturing employment. The authors stress the dominance of the "imported input" channel in this relationship. Lysenko (2019) suggests that the appreciation in REER decreases employment in manufacturing in the long run. This negative relationship is more obvious in the tradable sectors.

The summary of the literature review can be seen in the Table 1.

Table 1. The Summary of The Literature Review

\begin{tabular}{|c|c|c|c|}
\hline \multicolumn{4}{|c|}{ Category 1: REER- Employment (sectoral level) } \\
\hline Author(s) & $\begin{array}{l}\text { Empirical } \\
\text { Method }\end{array}$ & Period- Country & Main Findings \\
\hline Branson \& Love (1988) & $\operatorname{AR}(1)$ & $\begin{array}{l}\text { 1970-1986 quarterly, } \\
\text { the U.S., Japan }\end{array}$ & $\begin{array}{l}\text { The depreciation of the REER affects the employment } \\
\text { level in the durable goods sector. }\end{array}$ \\
\hline Glick \& Hutchinson (1990) & $2 S L S$ & 1957:1-1987:1, U.S. & $\begin{array}{l}\text { Dollar appreciation has an unstable, sample-specific effect } \\
\text { on sectoral employment. }\end{array}$ \\
\hline Revenga (1992) & $2 S L S$ & $\begin{array}{l}\text { 1977-1987, } \\
\text { United States }\end{array}$ & $\begin{array}{l}\text { The depreciation of the U.S. dollar decreased } \\
\text { employment in the trade-affected industries. }\end{array}$ \\
\hline Burgess \& Knetter (1998) & Panel OLS & 1972-1988 & Employment is significantly related to REER movements. \\
\hline Dekle (1998) & $2 S L S$ & 1975-1994, Japan & $\begin{array}{l}\text { The higher is the competitiveness of the industry, the } \\
\text { greater will be the response of the employment to the } \\
\text { REER. }\end{array}$ \\
\hline Gourinchas (1999) & Impulse response & 1984-1992, France & $\begin{array}{l}1 \% \text { appreciation of the REER affects the tradable jobs } \\
\text { negatively by } 0,95 \% \text { over the next two years. }\end{array}$ \\
\hline Campa \& Goldberg (2001) & $2 S L S$ & 1972-1995, U.S. & $\begin{array}{l}\text { Industries with more educated workers indicate lower } \\
\text { employment elasticities to the exchange rate changes. }\end{array}$ \\
\hline Kandil \& Mirzaie (2003) & Non-linear 3 SLS & 1961-2000, U.S. & $\begin{array}{l}\text { The appreciation has a negative effect in the construction } \\
\text { sector but a positive effect in the mining sector. }\end{array}$ \\
\hline Filiztekin (2004) & Panel OLS & 1981-1999, Turkey & $\begin{array}{l}10 \% \text { depreciation of the Turkish lira causes a } 1.6 \% \text { decline } \\
\text { in manufacturing employment. }\end{array}$ \\
\hline Bilgin \& Danis (2005) & AEG test & 1995-2004, Turkey & $\begin{array}{l}\text { No consensus about the sign and strength of the } \\
\text { relationship. It can differ from sector to sector and from } \\
\text { country to country. }\end{array}$ \\
\hline Bahmani-Oskooee et al. (2007) & ARDL & 1961-2000, U.S. & $\begin{array}{l}\text { Real depreciation of the dollar has a short-run positive } \\
\text { effect on employment but this effect disappears in the } \\
\text { long run. }\end{array}$ \\
\hline Hua (2007) & GMM & 1993-2002, China & $\begin{array}{l}\text { The revaluation of the Yuan has a significant negative } \\
\text { effect on Chinese manufacturing employment via the } \\
\text { technology channel. }\end{array}$ \\
\hline Ngandu (2008) & CGE model & undefined, South Africa & $\begin{array}{l}\text { The response of the employment level may differ from } \\
\text { sector to sector. }\end{array}$ \\
\hline Demir (2010) & GARCH & 1983-2005, Turkey & $\begin{array}{l}\text { The REER volatility has a significant negative effect on } \\
\text { employment growth in high export-intensive firms. }\end{array}$ \\
\hline Dao \& Chen (2011) & Panel OLS & 1980-2008, China & $\begin{array}{l}\text { The appreciation of the REER has a strong negative effect } \\
\text { on employment in both tradable and non-tradable } \\
\text { sectors. }\end{array}$ \\
\hline Alexandre (2011) & OLS & 1988-2006. Portuguese & $\begin{array}{l}\text { Employment in high-technology sectors does not seem to } \\
\text { be sensitive to exchange rate movements. }\end{array}$ \\
\hline Huang et al. (2014) & GMM & 1982-2012, Canada & $\begin{array}{l}\text { Appreciation of the Canadian dollar has significant effects } \\
\text { on employment in the manufacturing sector. }\end{array}$ \\
\hline Zmani-Ben Salha (2015) & GMM & 1997-2002, Tunisia & $\begin{array}{l}\text { Depreciation of the real effective and bilateral exchange } \\
\text { rate has a positive effect on employment in all sectors } \\
\text { with different elasticities. }\end{array}$ \\
\hline
\end{tabular}


The Real Effective Exchange Rate and Industrial Employment: The Turkish Case

Table 1. The Summary of The Literature Review (Continued)

\begin{tabular}{|c|c|c|c|}
\hline Paleaz (2016) & GMM & 2000-2010, Colombia & $\begin{array}{l}\text { Depreciation of the REER affects employment in the } \\
\text { manufacturing sector but with different responses at the } \\
\text { sub-sector level. }\end{array}$ \\
\hline Alexandre (2017) & OLS & $\begin{array}{l}\text { 1988-2006, } \\
\text { OECD countries }\end{array}$ & $\begin{array}{l}\text { The exchange rate elasticity of labor is low in sectors that } \\
\text { use low- and medium-low technology. }\end{array}$ \\
\hline Dogan \& Islam (2018) & GMM & 2006-2015, Turkey & $\begin{array}{l}\text { Appreciation of the REER increases employment in the } \\
\text { manufacturing sector. The positive relationship is } \\
\text { explained via the "imported input channel." }\end{array}$ \\
\hline Lysenko (2019) & ARDL & 1962-2004, Canada & $\begin{array}{l}\text { Appreciation of the REER decreases employment in the } \\
\text { long run. The decrease is higher in tradable sectors. }\end{array}$ \\
\hline \multicolumn{4}{|c|}{ Category 2: REER- Employment (country level) } \\
\hline Faria \& Leon-Ladesma (2005) & DOLS, FMOLS & $\begin{array}{l}\text { 1972:1-2001:4; U.S., } \\
\text { UK }\end{array}$ & $\begin{array}{l}\text { Appreciation of REER affects employment positively in the } \\
\text { UK but negatively in the US. }\end{array}$ \\
\hline Xiangquan et al. (2011) & $\begin{array}{l}\text { VAR, Impulse } \\
\text { response }\end{array}$ & 1978-2007, China & $\begin{array}{l}\text { A competitive and stable exchange rate is crucial for the } \\
\text { creation of employment. }\end{array}$ \\
\hline Sahin \& Cengiz (2011) & DOLS, FMOLS & 2003:1-2009:4, Turkey & $\begin{array}{l}\text { A negative relationship between REER appreciation and } \\
\text { employment growth. }\end{array}$ \\
\hline Mpofu (2013) & OLS & $\begin{array}{l}\text { 1995-2010, South } \\
\text { Africa }\end{array}$ & $\begin{array}{l}\text { REER volatility has a significant counteracting effect on } \\
\text { manufacturing employment growth both in the short- and } \\
\text { in the long run. }\end{array}$ \\
\hline Ay \& Ayhan (2016) & ARDL, EGARCH & $\begin{array}{l}\text { 2003:1-2014:12, } \\
\text { Turkey }\end{array}$ & $\begin{array}{l}\text { The volatility of the exchange rate affects employment } \\
\text { negatively. }\end{array}$ \\
\hline Chipeta (2017) & $\begin{array}{l}\text { VAR, VECM, } \\
\text { Granger causality, } \\
\text { impulse response }\end{array}$ & $\begin{array}{l}\text { 1995-2015, quarterly, } \\
\text { South Africa }\end{array}$ & $\begin{array}{l}\text { Depreciation of the REER decreases the overall } \\
\text { employment level. }\end{array}$ \\
\hline \multicolumn{4}{|c|}{ Category 3: REER- Unemployment (country level) } \\
\hline Boz (2013) & OLS & $\begin{array}{l}\text { 2003:1-2012:3, } \\
\text { quarterly, Turkey }\end{array}$ & $\begin{array}{l}\text { A positive relationship between REER appreciation and } \\
\text { unemployment. }\end{array}$ \\
\hline Nyahokwe (2013) & $\begin{array}{l}\text { VAR, GARCH, } \\
\text { Impulse response }\end{array}$ & $\begin{array}{l}\text { 2000-2017, quarterly, } \\
\text { South Africa }\end{array}$ & $\begin{array}{l}\text { Depreciation of the REER has a minor effect on the } \\
\text { increase in unemployment but the impact of volatility of } \\
\text { the REER is high and significantly negative over the }\end{array}$ \\
\hline Bakshi \& Ebrahimi (2016) & ARDL & $1981-2012$ & $\begin{array}{l}\text { A negative relationship between unemployment and real } \\
\text { exchange rate. }\end{array}$ \\
\hline Usman \& El Salih (2018) & ARDL & 1981M1-2015M11 & $\begin{array}{l}\text { The response of the unemployment rate to the } \\
\text { appreciation and depreciation of the domestic currency is } \\
\text { asymmetric. }\end{array}$ \\
\hline Akarsu (2020) & VAR & $\begin{array}{l}\text { 2005-2019, quarterly, } \\
\text { Turkey }\end{array}$ & $\begin{array}{l}\text { No relationship between REER and unemployment but a } \\
\text { positive relationship between exchange rate volatility and } \\
\text { unemployment. }\end{array}$ \\
\hline
\end{tabular}

\section{The Importance of Country Specific Economic Facts: Turkish Case}

The existing literature shows that the country-specific and sector-specific differences can influence the relationship between REER and employment. This information led us to review the country-specific facts of the Turkish economy after the year 2000 while the world entered a new period called Bretton Woods II system in which the Turkish economy became more open to trade and capital flows ${ }^{2}$.

The new millennium did not start very well for the Turkish economy which experienced an economic crisis in 2001 due to the serious problems in the banking sector. The recovery period was quick with the help of the IMF-supported economic program and the crisis came to an end with the introduction of some structural reforms in the financial system and public sector. New binding policy rules were introduced to strengthen the banking system and to discipline public finance. Also, the exchange rate system was transformed from the currency band to a flexible exchange rate system (Bredenkamp, Josefsson, Lindgren, \& Serdengeçti, 2009). Meanwhile, the economic slowdown in the U.S. economy at the beginning of the year 2000 led the FED to conduct expansionary monetary policy which relied on very low interest rates. The energy producer countries benefitted also from the increasing aggregate demand and energy prices in this period and created huge current account surpluses like the leading exporter Japan, Germany, and China. These excess savings were used as the source of cheap credits on a global scale (Obstfeld \& Rogoff, 2009). The 
availability of the funds helped many emerging market countries, including Turkey, to grow economically higher than their potential between the years 2002-2007, until the "Great Recession" in 20083. During the 2002-2007 period, the structural reforms and the accession negotiations with the EU had worked as an anchor for economic growth. The foreign direct and portfolio investments started to come to Turkey in massive amounts which led to an appreciation of the Turkish Lira against the major reserve currencies. The CPI- and PPI-based inflation decreased to one-digit levels after 2004. The CPI- and PPI-based real exchange rates $(2003=100)$ raised above 100 points after 2003 which means an appreciation of the real exchange rate. The total factor productivity (TFP) has also started to increase after 2002 which may be explained by the "efficiency improvement" and "technology" transmission channels suggested by Hua (2007). The economic miracle period ended with the beginning of the Great Recession in 2008. The negative effect of the Great Recession gave place to economic recovery in most of the emerging market countries, including Turkey, after 2010 which lasted until the "tapering" announcement of FED in May 2013 ${ }^{4}$. Starting from that date, the foreign direct and portfolio investments started to decrease in the Turkish economy. The Turkish Lira depreciated against reserve currencies like the US dollar and the Euro. The PPI- and CPI-based inflation rates reached two-digit levels after the year 2016. The PPI- and CPI-based real exchange rates decreased below 100 points which means a cost advantage in international trade and relatively cheap domestic prices for the foreigners. The changes in these variables can be seen in Table 2 over the period 2000-2019.

Table 2. The Changing Structure of The Economy After 2000

\begin{tabular}{|c|c|c|c|c|c|c|c|}
\hline & FDI (mil. USD) & PI (mil. USD) & CPI (\%) & PPI(\%) & TFP growth & REER-CPI & REER-PPI \\
\hline 2000 & 138 & 3,429 & $55 \%$ & $51 \%$ & $3.79 \%$ & 116 & 111 \\
\hline 2001 & 112 & 1,022 & $54 \%$ & $62 \%$ & $-6.78 \%$ & 90 & 89 \\
\hline 2002 & 2,855 & $-4,515$ & $45 \%$ & $50 \%$ & $4.49 \%$ & 96 & 94 \\
\hline 2003 & 939 & -593 & $22 \%$ & $26 \%$ & $2.80 \%$ & 101 & 99 \\
\hline 2004 & 1,222 & 2,465 & $9 \%$ & $11 \%$ & $5.04 \%$ & 102 & 101 \\
\hline 2005 & 2,005 & 8,023 & $8 \%$ & $8 \%$ & $1.40 \%$ & 119 & 112 \\
\hline 2006 & 8,967 & 13,457 & $10 \%$ & $10 \%$ & $-0.24 \%$ & 110 & 103 \\
\hline 2007 & 19,261 & 7,415 & $9 \%$ & $6 \%$ & $-0.46 \%$ & 128 & 115 \\
\hline 2008 & 19,941 & 833 & $10 \%$ & $13 \%$ & $-4.10 \%$ & 111 & 102 \\
\hline 2009 & 17,302 & $-5,014$ & $6 \%$ & $1 \%$ & $-6.64 \%$ & 114 & 105 \\
\hline 2010 & 7,032 & 227 & $9 \%$ & $9 \%$ & $2.32 \%$ & 120 & 111 \\
\hline 2011 & 7,617 & 16,083 & $6 \%$ & $11 \%$ & $3.62 \%$ & 103 & 98 \\
\hline 2012 & 13,812 & 22,204 & $9 \%$ & $6 \%$ & $-0.60 \%$ & 111 & 104 \\
\hline 2013 & 9,638 & 41,029 & $7 \%$ & $4 \%$ & $2.92 \%$ & 101 & 95 \\
\hline 2014 & 9,927 & 24,020 & $9 \%$ & $10 \%$ & $-0.25 \%$ & 106 & 102 \\
\hline 2015 & 6,287 & 20,216 & $8 \%$ & $5 \%$ & $0.14 \%$ & 99 & 97 \\
\hline 2016 & 14,167 & $-15,349$ & $8 \%$ & $4 \%$ & $-1.84 \%$ & 94 & 91 \\
\hline 2017 & 10,791 & 6,412 & $11 \%$ & $16 \%$ & $1.44 \%$ & 86 & 84 \\
\hline 2018 & 8,398 & 24,063 & $16 \%$ & $27 \%$ & $-1.70 \%$ & 76 & 83 \\
\hline 2019 & 9,374 & $-3,115$ & $15 \%$ & $18 \%$ & $-0.89 \%$ & 76 & 81 \\
\hline
\end{tabular}

Source: Central Bank of Turkey, Turkish Statistical Institution.

The effect of these developments on the employment structure after the year 2000 is represented in Figure 1. The most apparent change has been the decrease of the agricultural sector's share in the total employment and the increase in the share of the services sector in the total employment. The share of agricultural employment decreased from $36 \%$ in 2000 to $19.8 \%$ in 2019 while the share of the services sector rose from $40 \%$ to $56.53 \%$. The share of the construction sector was $6.3 \%$ in 2000 and $5.52 \%$ in 2019 . On the other hand, this rate had been fluctuating around 7\% over the period 2011-2018. There is a slight increase in the share of industrial employment which was $17.7 \%$ in 2000 and decreased to $19.80 \%$ level in 2019. 
Figure 1. The Sectoral Employment Shares (2000-2019)

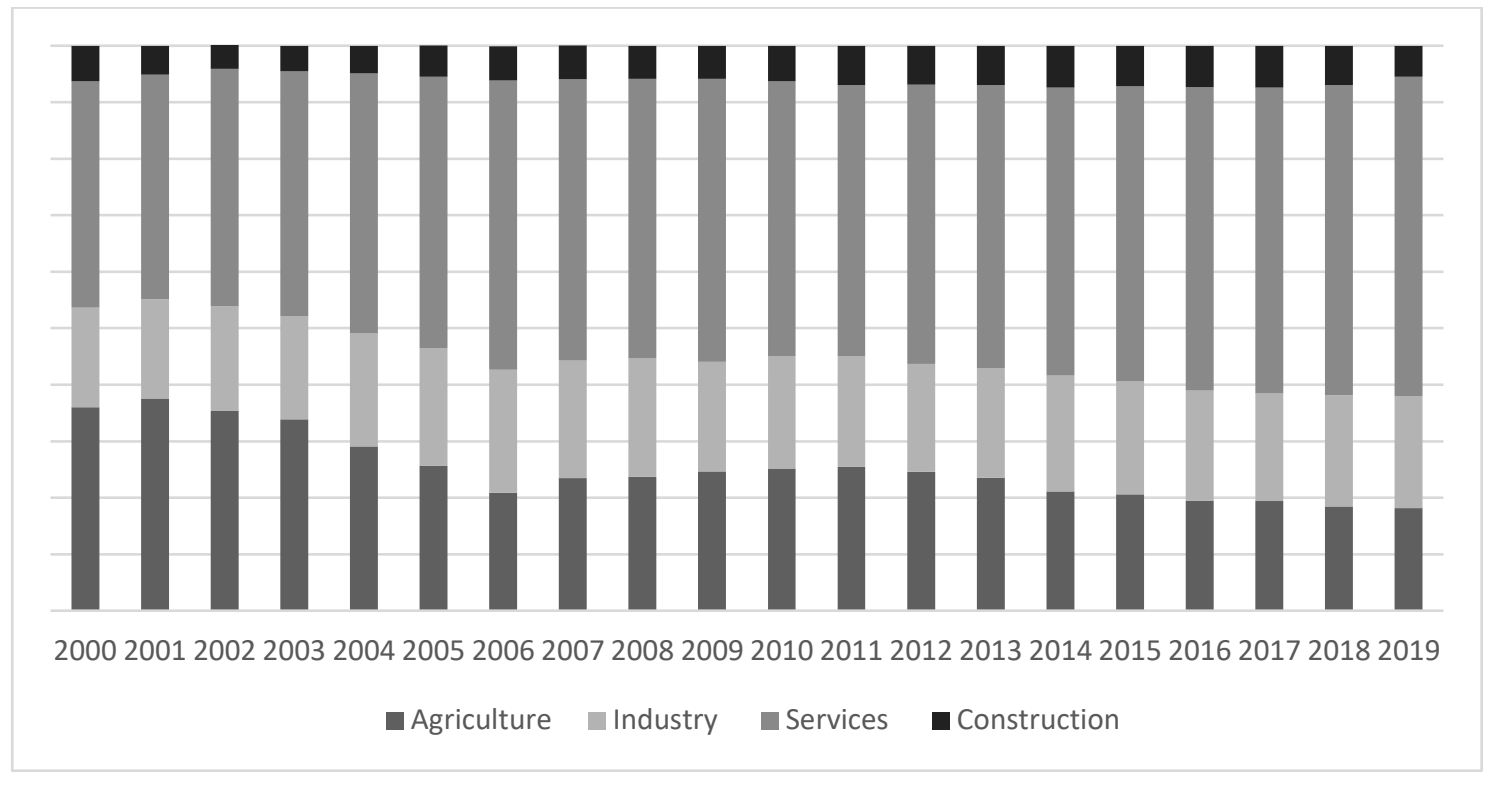

Source: Turkish Statistical Institute.

Since the main aim of the study is the empirical investigation of the REER-employment relationship, the visual investigation of these two variables may be a good starting point. Figure 2 shows the monthly data series of the variables over the period 2009-2019. The left scale of Figure 2 shows the REER-PPI values $(2003=100)$ while the right scale shows the number of industrial employees, I-EMP, in thousands.

Figure 2. The PPI Based REER and Industrial Employment (2009M1-2019M10)

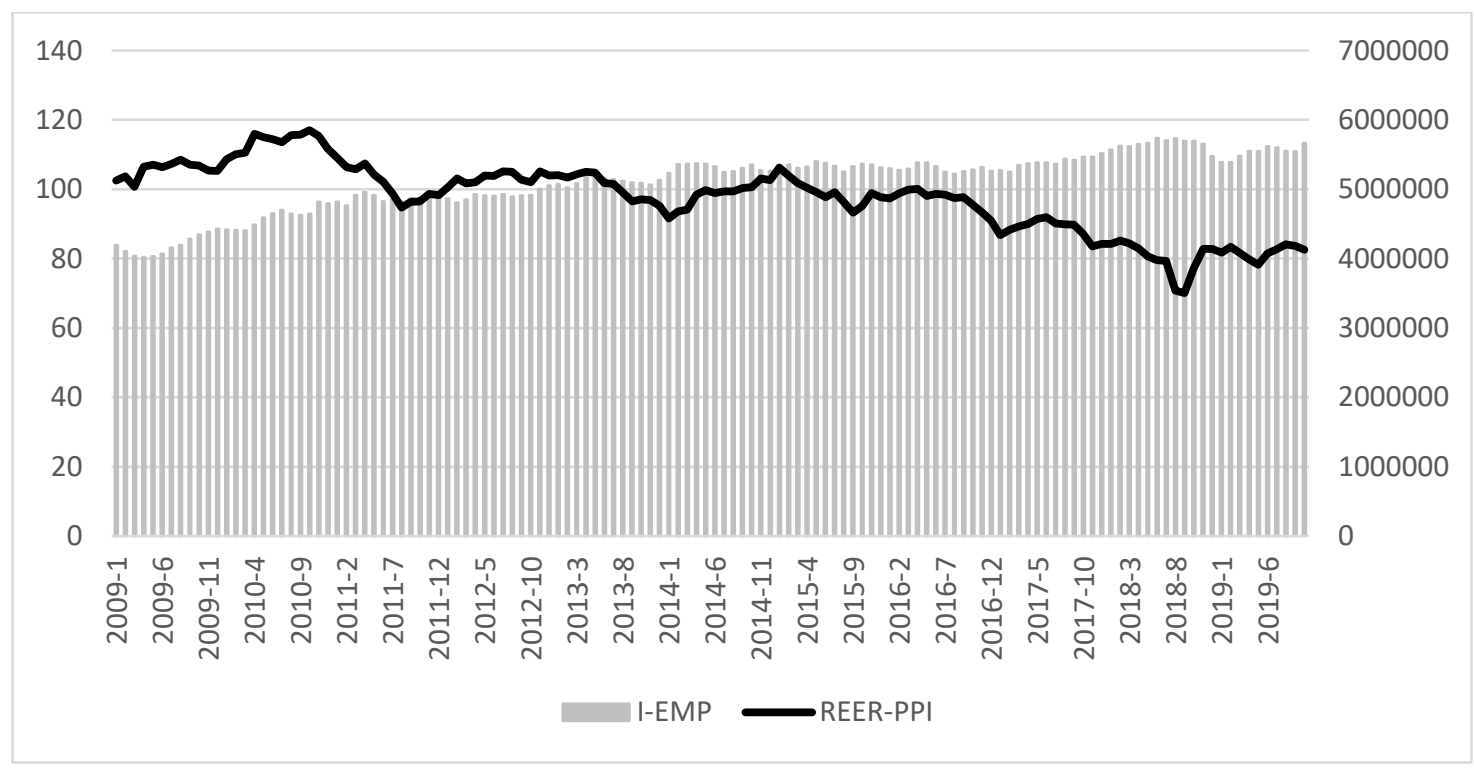

Source: Central Bank of Turkey. 
The dark line represents the changes in the REER-PPI and the bars represent the changes in I-EMP. At first glance, the depreciation of the REER-PPI and the increase of the I-EMP in this period fulfills the expected theoretical relationship based on the transmission channels of Frenkel and Ros (2006) and Hua (2007). On the other hand, this visual relationship needs supportive empirical evidence. Besides, the graphical representation does not take the time lags into account. Moreover, the REER-PPI is not the only source of the employment changes, and the counter effects of the "imported input" channel may change the direction of the expected REER-employment relationship.

\section{Empirical Investigation}

\subsection{Data and Variables}

The previous empirical studies mostly employed quarterly and annual data to explore the relationship between REER and employment. As far as we know our study has been one of the few studies that use monthly data for the empirical investigation ${ }^{5}$. We expect that the monthly frequency of the data helps us to determine the appropriate time lags which provides more accurate findings for the relationship. We used two main data sources for the empirical investigation covered the period 2009M01-2019M10. The employment data is obtained from the Turkish Statistical Institute (STI) while the data for all other variables are obtained from the database of the Central Bank of Turkey (CBRT).

\subsection{Model Specification}

The existing empirical literature indicates that some other variables are used in different studies to explore the relationship between employment level and the changes in REER. The most commonly used explanatory variables are real GDP level, energy price, wage rate, real interest rate, and export. Under the light of the existing empirical literature, we estimate the following model which aims to explain the changes in the industrial employment (IEMP) with the following five explanatory variables; (i) industrial production index (IPI), (ii) export volume $(X)$, (iii) PPI-based real effective exchange rate (REER), (iv) banking credits to the private sector $(B C)$, and $(v)$ foreign direct investments $(F D I)$.

$$
I E M P=F(I P I, R E E R, X, B C, F D I)
$$

As we mention in the previous chapter, the country, and industry-specific differences may affect the direction and strength of the relationship. The choice about the "banking credits to the private sector" $(B C)$ and "foreign direct investment" $(F D I)$ as the two new variables depend on the country-specific differences for Turkey. Some of the emerging market countries like Brazil, Argentina, Mexico, Turkey are chronic dissavers which means that these countries need some foreign funds, in the form of direct or portfolio investments, to close the gap between domestic savings and investments. Direct foreign investments can affect employment directly by opening new businesses or buying a minimum of 10 percent of the shares of domestic companies. On contrary, the portfolio investments are in the form of "hot money". These foreign sources are used as an important source for domestic credits to private firms and households. In this context, $B C$ and $F D I$ play an important role in the creation of new employment opportunities for the Turkish case. Our choice about the industrial production index (IPI) instead of real GDP depends basically on two reasons; (i) IPI allows us to use monthly data and (ii) it is an indicator that represents the industrial output changes which are directly related to the industrial employment. The variable export volume $(X)$ is another important explanatory variable in our model since $94.1 \%$ of the total exports of Turkey were made by the industrial sector in $2019^{6}$. As a result, we estimate the following simple log-linear functional model to explore industrial employment and real effective exchange rate relationship.

$$
\operatorname{LIEMP}_{t}=\beta_{0}+\beta_{1} L I P I_{t}+\beta_{2} L R E E R_{t}+\beta_{3} L X_{t}+\beta_{4} L B C_{t}+\beta_{5} L F D I_{t}+\varepsilon_{t}
$$


The capital letter $(L)$ before the variables represents the logarithm of each series. This functional formulation will be the starting point of our research for the long-run and short-run relationships. There are several techniques to explore the cointegration between the variables like the residual-based Engle-Granger (1987), maximum likelihood-based Johansen $(1991,1992)$, and Johansen and Juselius (1990) tests. All these tests require that the variables in the model be integrated in the same order. In this regard, we prefer to employ the Autoregressive Distributive Lag (ARDL) bounds testing approach to cointegration which was originally introduced by Pesaran and Shin (1999) and developed by Pesaran et al. (2001). The ARDL approach has some advantages over the former cointegration techniques; (i) the ARDL is being applied irrespectively the order of integration of the variable $I_{0}$ or $I_{1}$, (ii) the short-run and long-run coefficients of the model can be estimated simultaneously, (iii) it is better suited to small samples.

The ARDL representation of equation (2) is formulated in equation (3) where $(\Delta)$ is the first difference operator, $(n)$ is the optimal lag length, and $\left(\alpha_{0}\right)$ is the deterministic drift parameter.

$$
\begin{aligned}
\Delta \text { LIEMP }_{t}=\alpha_{0} & +\sum_{i=1}^{n} \alpha_{1 i} \Delta \operatorname{LIEMP}_{t-i}+\sum_{i=0}^{n} \alpha_{2 i} \Delta L I P I_{t-i}+\sum_{i=0}^{n} \alpha_{3 i} \Delta L R E E R_{t-i} \\
& +\sum_{i=0}^{n} \alpha_{4 i} \Delta L X_{t-i}+\sum_{i=0}^{n} \alpha_{5 i} \Delta L B C_{t-i}+\sum_{i=0}^{n} \alpha_{6 i} \Delta L F D I_{t-i}+\beta_{1} L I E M P_{t-1} \\
& +\beta_{2} L I P I_{t-1}+\beta_{3} L R E E R_{t-1}+\beta_{4} L X_{t-1}+\beta_{5} L B C_{t-1}+\beta_{6} L F D I_{t-1}+v_{t 1}
\end{aligned}
$$

The first part of the equation (3) with $\alpha_{1 i}, \alpha_{2 i}, \alpha_{3 i}, \alpha_{4 i}, \alpha_{5 i}, \alpha_{6 i}$ refer to the short-run parameters while the $\beta^{\prime}$ s in the rest of the equation is long-run parameters. We test the null hypothesis for no cointegration $H_{0}: \beta_{1}=\beta_{2}=\beta_{3}=\beta_{4}=\beta_{5}=\beta_{6}=0$ and the alternate hypothesis $H_{A}: \beta_{1} \neq \beta_{2} \neq \beta_{3} \neq$ $\beta_{4} \neq \beta_{5} \neq \beta_{6} \neq 0$ by conducting a non-standard F-test to find the existence of a relationship between the variables in the long run. This test involves two asymptotic critical value bounds developed by Pesaran et al. (2001). If the calculated F-statistics exceeds the upper critical bound, we decide on a long-run cointegration. If the F-statistics is below the lower critical bound there is no cointegration. If the calculated F-statistics is between these two bounds the decision about cointegration is ambiguous. If we can reject the null hypothesis of no cointegration statistically and decide for the cointegration in the long run, we can estimate the following unrestricted error correction model (ECM) which indicates the short-run dynamics of the model;

$$
\begin{aligned}
\Delta L I E M P_{t}=\alpha_{0} & +\sum_{i=1}^{n} \alpha_{1 i} \Delta L I E M P_{t-i}+\sum_{i=0}^{n} \alpha_{2 i} \Delta L I P I_{t-i}+\sum_{i=0}^{n} \alpha_{3 i} \Delta L R E E R_{t-i} \\
& +\sum_{i=0}^{n} \alpha_{4 i} \Delta L X_{t-i}+\sum_{i=0}^{n} \alpha_{5 i} \Delta L B C_{t-i}+\sum_{i=0}^{n} \alpha_{6 i} \Delta L F D I_{t-i}+\lambda E C_{t-1}+u_{t}
\end{aligned}
$$

where $\left(\lambda E C_{t-1}\right)$ represents the coefficient error correction term $(E C)$ with the speed of the adjustment parameter $(\lambda)$ which says us how quickly variables converge to the long-run equilibrium. The negative value of the coefficient error correction term, which is statistically significant, is interpreted as the existence of the short-run relationships between the variables.

\subsection{Test Procedure}

The test procedure of our research starts with the unit root test to determine the degree of stationarity of the series. The second step is to explore the significant relationship between the dependent and explanatory variables in the short run and the long run by employing the ARDL bounds testing. The third step is to make the diagnostics tests which provide us information about the adequacy of our empirical model. 


\subsubsection{Unit Root Test}

The ADF, Philips Peron, and KPSS unit root test results are represented in the following three tables. According to the ARDL approach, the variables should be integrated at I(0) and I(1). Besides we have to decide whether the series has only (i) intercept, (ii) only trend, (iii) intercept and trend, or (iv) none. The graphs of the variables show that all variables except the LFDI have both intercept and trend, while LFDI has only intercept.

The results of ADF, Philips Peron, and KPSS unit root test indicate that all variables are stationary either at I (0) or at I (1) which allows us to continue with the ARDL procedure. Some values in the following three tables are italic and colored bold to indicate that these values are used to represent the stationarity of the series. For instance, the variable LIEMP has both trends and intercept graphically, and it is stationary at the level with the probability of the t-statistics 0.017 . Hence, we colored the value $(3.7324)$ bold and put $\left({ }^{* *}\right)$ to express that the result is significant at a $5 \%$ level.

Table 3. ADF Unit Root Test Results (max lag=10, AIC automatic selection)

\begin{tabular}{|c|c|c|c|c|}
\hline \multirow{2}{*}{ Variables } & \multicolumn{2}{|c|}{ Intercept } & \multicolumn{2}{c|}{ Intercept + Trend } \\
\cline { 2 - 5 } & Level & First diff. & Level & First diff. \\
\hline LIEMP & $-3.5466^{* *}$ & $-5.4338^{*}$ & $\mathbf{3 , 7 2 3 4 ^ { * * }}$ & $-5.9365^{*}$ \\
\hline LIPI & $-2.5838^{* * *}$ & $-8.2207^{*}$ & -1.9302 & $\mathbf{- 9 . 7 8 4 0 ^ { * }}$ \\
\hline LREER & -0.9017 & $-8.4546^{*}$ & $-3.4173^{* * *}$ & $-\mathbf{8 . 4 7 2 5 *}$ \\
\hline LX & $-2.7715^{* * *}$ & $-4.6663^{*}$ & -2.3023 & $-\mathbf{4 . 7 1 4 6 ^ { * }}$ \\
\hline LFDI & $-4.7289^{*}$ & $-5.8650^{*}$ & $-4.9603^{*}$ & $-5.8595^{*}$ \\
\hline LBC & -2.5595 & $-9.1041^{*}$ & 0.2896 & $\mathbf{- 9 . 5 5 4 8 ^ { * }}$ \\
\hline
\end{tabular}

Note: $\left({ }^{*}\right),\left({ }^{* *}\right)$ and $\left({ }^{* * *}\right)$ denote significance at $1 \%, 5 \%$ and $10 \%$, respectively.

Table 4. Philips Peron Unit Root Test Results (Newey-West Bandwidth=4, automatic selection)

\begin{tabular}{|c|c|c|c|c|}
\hline \multirow{2}{*}{ Variables } & \multicolumn{2}{|c|}{ Intercept } & \multicolumn{2}{c|}{ Intercept + Trend } \\
\cline { 2 - 5 } & Level & First diff. & Level & First diff. \\
\hline LIEMP & -2.1776 & $-8.9824^{*}$ & -1.8272 & $\mathbf{- 9 . 3 8 9 8 ^ { * }}$ \\
\hline LIPI & $-3.1431^{* *}$ & $-35.3858^{*}$ & $\mathbf{- 8 . 4 0 7 2 *}$ & $-53.2115^{*}$ \\
\hline LREER & -1.1052 & $-9.2070^{*}$ & -2.9128 & $-\mathbf{9 . 1 7 9 5 *}$ \\
\hline LX & $-3.9205^{*}$ & $-35.4639^{*}$ & $-7.070^{*}$ & $-40.2293^{*}$ \\
\hline LFDI & $-10.0655^{*}$ & $-45.3128^{*}$ & -10.2003 & $-\mathbf{8 7 . 5 8 8 7 ^ { * }}$ \\
\hline LBC & -2.3377 & $-9.0397^{*}$ & 0.0098 & $\mathbf{- 9 . 3 7 8 1 ^ { * }}$ \\
\hline
\end{tabular}

Note: $\left({ }^{*}\right),\left({ }^{* *}\right)$ and $\left({ }^{* *}\right)$ denote significance at $1 \%, 5 \%$ and $10 \%$, respectively.

Table 5. KPSS Test Results (Newey-West Bandwidth=4, automatic selection)

\begin{tabular}{|c|c|c|c|c|}
\hline \multirow{2}{*}{ Variables } & \multicolumn{2}{|c|}{ Intercept } & \multicolumn{2}{c|}{ Intercept + Trend } \\
\cline { 2 - 5 } & Level & First diff. & Level & First diff. \\
\hline LIEMP & 1.2230 & $0.2314^{*}$ & 0.2579 & $\mathbf{0 . 0 4 2 7}^{*}$ \\
\hline LIPI & 1.3259 & $0.2848^{*}$ & 0.3218 & $\mathbf{0 . 1 2 1 8}^{* *}$ \\
\hline LREER & 1.1013 & $0.0746^{*}$ & 0.1742 & $\mathbf{0 . 0 3 9 5}^{*}$ \\
\hline LX & 0.9263 & $0.2294^{* *}$ & 0.2337 & $\mathbf{0 . 1 5 5 1}^{* *}$ \\
\hline LFDI & $\mathbf{0 . 3 7 0 5 * *}$ & $0.1862^{*}$ & 0.2423 & $0.1531^{* *}$ \\
\hline LBC & 1.3703 & $0.5353^{* *}$ & 0.3096 & $\mathbf{0 . 0 7 2 2}^{*}$ \\
\hline
\end{tabular}

Note: $\left({ }^{*}\right),\left({ }^{* *}\right)$ and $\left({ }^{* * *}\right)$ denote significance at $1 \%, 5 \%$ and $10 \%$, respectively. 


\subsubsection{Cointegration Test (Long Run Bounds Test and Short Run ECM)}

In this section, the long-run and short-run relationship between industrial employment and the explanatory variables are examined using the ARDL bounds testing and Error Correction procedure respectively. The first step is to run the ARDL procedure to estimate the ARDL model with the optimal laglength selection. We employ the Akaike Information Criteria (AIC) for the optimal lag length and the "fixed regressors trend" specification was specified as "constant". As a result, the ARDL $(5,2,0,0,4,0)$ model was selected. The next step is to explore a significant long-run relationship for this ARDL model. The bounds test result can be seen in Table 6 and Table 7. The F-statistics in Table 6 shows that there is a significant relationship between the variables in the long run. The long-run results reported in Table 7 indicate that an increase in the exports, banking credits to the private sector, and the real effective exchange rate by $1 \%$ has a statistically significant positive effect on industrial employment by $0.1515 \%, 0.0916 \%$, and $0.0920 \%$ respectively. On the other hand, the test results show that the relationship of industrial employment with foreign direct investments and the industrial production index is statistically insignificant.

Table 6. Bounds F-test for Cointegration

\begin{tabular}{|l|c|c|c|}
\hline \multicolumn{1}{|c|}{ Dependent Variable } & \multicolumn{2}{|c|}{ F-Statistics } \\
\hline \multicolumn{1}{|c|}{ LIEMP } & F(LIEMP/LIPI,LREER,LX,LBC,LFDI) & \multicolumn{2}{|c|}{$7,3649 *$} \\
\hline Asymptotic Critical Values & $\mathrm{I}(0)$ & $\mathrm{I}(1)$ \\
\hline $1 \%$ significance & 3.41 & 4.68 \\
\hline $2.5 \%$ significance & 2.96 & 4.18 \\
\hline $5 \%$ significance & 2.62 & 3.79 \\
\hline $10 \%$ significance & 2.26 & 3.35 \\
\hline
\end{tabular}

Note: The significance levels were taken from Table Cl (iii) Case III, Pesaran et al. (2001) (*) denotes statistical significance at $1 \%$ level.

The direction of the relationship between real effective exchange rate and industrial employment is especially important for us since it is the main interest of our research. As can be seen in the third row of Table 7, there is a significant positive relationship between these two variables. This positive result may be interpreted as the dominance of the "imported input" and "market structure" channels over the other transmission channels like "development" and "macroeconomic" channels which advocate the negative relationship between the appreciation of the real effective exchange rate and employment level.

Table 7. Estimated Long-Run Coefficients Using ARDL $(5,2,0,0,4,0)$

\begin{tabular}{|c|c|c|c|c|}
\hline \multicolumn{5}{|c|}{ Long-run Coefficients- Dependent variable is LEMP } \\
\hline Regressor & Coefficient & Standard Error & t-Statistics & Probability \\
\hline LIPI & -0.0080 & 0.0639 & -0.1265 & 0.8995 \\
\hline LREER & $0.0920^{* *}$ & 0.04194 & 2.1945 & 0.0303 \\
\hline LX & $0.1515^{*}$ & 0.04199 & 3.6087 & 0.0005 \\
\hline LBC & $0.0916^{*}$ & 0.0155 & 5.9125 & 0.0000 \\
\hline LFDI & -0.0049 & 0.0039 & -1.2399 & 0.2177 \\
\hline
\end{tabular}

Note: $\left({ }^{*}\right),\left({ }^{* *}\right),\left({ }^{* * *}\right)$ denotes the significance levels $1 \%, 5 \%$ and $10 \%$ respectively.

The next step is to explore the short-run dynamics of the model. Table 8 represents the error correction form of the selected ARDL model $(5,2,0,0,4,0)$. The coefficient of the error correction term CointEq $(-1)$ is negative and significant which verifies the existence of a significant relationship between industrial employment and the explanatory variables in the short run. 
R. C. Akkay

Table 8. Error Correction Representation of The ARDL Model $(5,2,0,0,4,0)$

\begin{tabular}{|c|c|c|c|c|}
\hline \multicolumn{5}{|c|}{ Short-run Coefficients - Dependent variable DLEMP, D= first difference operator } \\
\hline Variables & Coefficient & Std. Error & t-Statistics & Prob. \\
\hline Constant & 2.3805 & 0.3502 & 6.7981 & 0.0000 \\
\hline $\mathrm{D}($ LEMP(-1)) & 0.2379 & 0.0748 & 3.1786 & 0.0019 \\
\hline $\mathrm{D}($ LEMP(-2)) & -0.0144 & 0.0741 & -0.1947 & 0.8459 \\
\hline $\mathrm{D}($ LEMP(-3)) & -0.2172 & 0.0739 & -2.9391 & 0.0040 \\
\hline $\mathrm{D}($ LEMP(-4)) & 0.3011 & 0.0738 & 4.0779 & 0.0001 \\
\hline $\mathrm{D}($ LIPI) & -0.0140 & 0.0088 & -1.5925 & 0.1142 \\
\hline $\mathrm{D}(\mathrm{LIPI}(-1))$ & 0.0238 & 0.0082 & 2.9024 & 0.0045 \\
\hline $\mathrm{D}(\mathrm{LBC})$ & 0.0503 & 0.0341 & 1.4739 & 0.1434 \\
\hline $\mathrm{D}($ LBC(-1)) & 0.1027 & 0.0345 & 2.9701 & 0.0037 \\
\hline $\mathrm{D}($ LBC(-2)) & 0.0516 & 0.0351 & 1.4681 & 0.1450 \\
\hline $\mathrm{D}($ LBC(-3)) & 0.0770 & 0.0353 & 2.1819 & 0.0313 \\
\hline CointEq(-1) & -0.2609 & $\mathbf{0 . 0 3 8 3}$ & -6.7996 & 0.0000 \\
\hline R-squared (0.4965), F-statistics (10.1309), Durbin-Watson stat (1.9551) & \\
\hline
\end{tabular}

The last step of the empirical investigation is to explore the adequacy of our model by employing some diagnostic tests. We employ three diagnostic tests to check normality, heteroskedasticity, and serial correlation of the residuals. The Jarque-Bera test result shows that residuals are normally distributed. The Lagrange Multiplier (LM) test of autocorrelation indicates that the residuals are not serially correlated and the BPG (Breusch-Pagan-Godfrey) test shows that the residuals are homoscedastic as can be seen in Table 9.

Table 9. Diagnostics Test

\begin{tabular}{|l|c|c|c|}
\hline Type of Diagnostics & Test & Test output & Test result \\
\hline \multirow{3}{*}{ Residual Diagnostics } & Normality test & $2.369(0.306)$ & normal distr. \\
\cline { 2 - 4 } & LM test & $0.542(0.743)$ & no serial corr. \\
\cline { 2 - 4 } & Heterosk. test (BPG) & $1.234(0.254)$ & homoskedastic \\
\hline \multirow{3}{*}{ Stability Diagnostics } & Ramsey Reset test & $0.5261(0.469)$ & correctly specified \\
\cline { 2 - 4 } & CUSUM & Figure 3 & no struct. break \\
\cline { 2 - 4 } & CUSUM of square & Figure 4 & no struct. break \\
\hline
\end{tabular}

Figure 3. Cumulative Sum of Recursive Residuals Plot

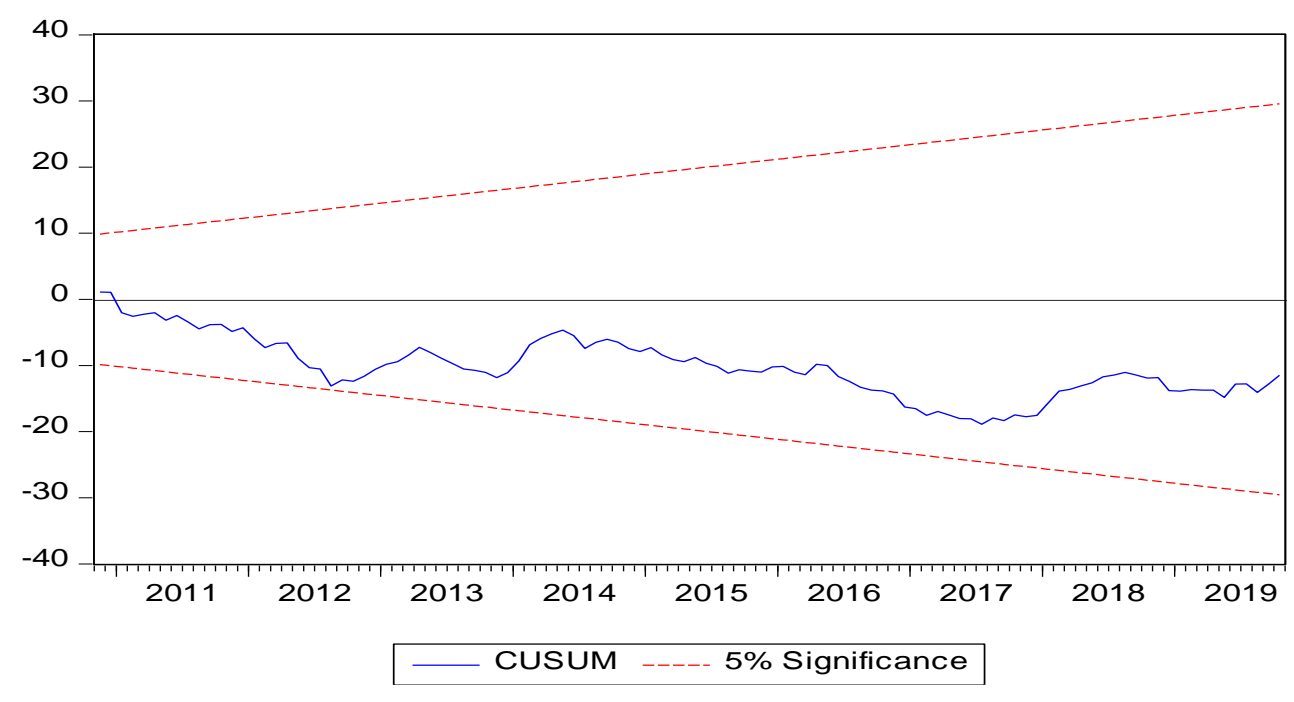


The stability diagnostics are checked through Ramsey RESET, CUSUM, and CUSUM of squares tests. Ramsey RESET test results show that our model is correctly specified. The other two stability diagnostic tests, CUSUM and CUSUM of square, are used to evaluate the stability of the regression coefficients. As can be seen from the graphical representation of the CUSUM and CUSUM of squares test our regression equation is stable over the period. As a result, our model passes the diagnostic tests for stability, heteroscedasticity, normality, and serial correlation.

Figure 4. Cumulative Sum of Squares of Recursive Residuals Plot

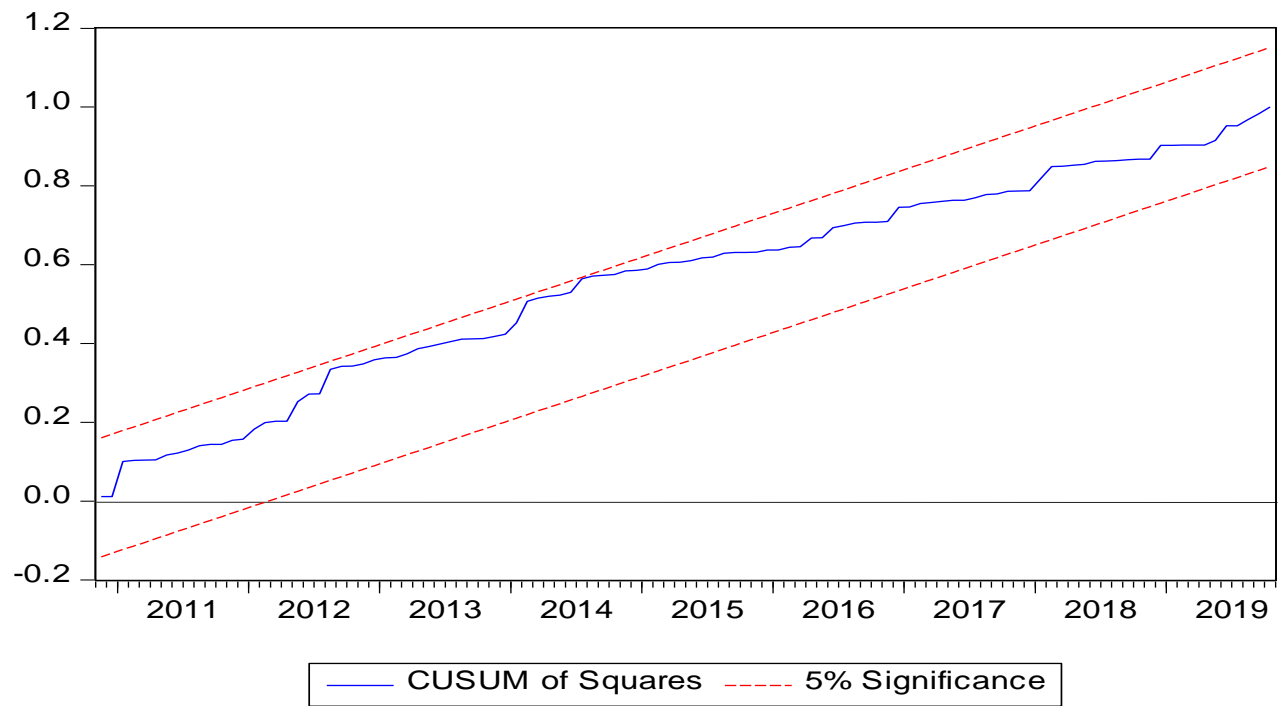

\section{Conclusion}

In this study, the "real effective exchange rate-industrial employment" relationship is examined empirically over the period 2009-2019 for the Turkish economy. The research period starts from the year 2009 to decrease the potential disturbances of the 2008 global financial crisis. The monthly data frequency is expected to provide more accurate test results about the relationship while the ARDL cointegration method allows us to examine the relationship both in the short- and in the long run.

The existing literature provides two pieces of important information. The first one is about the suggestion of different theoretical transmission channels that explain how the REER changes may affect employment levels positively or negatively. The second one is the empirical findings which support the theoretical approach about transmission channels and shows that the relationship may be positive, negative, or neutral at aggregate and disaggregate levels. These two pieces of information reveal the importance of the "country-specific facts" as the required link between the theoretical approach and empirical findings. In this manner, the country-specific facts for the Turkish economy were examined over the period 2000-2019 which also covers our empirical research period 2009-2019. The choice about a wider period for the examination of the country-specific developments stems from the fact that the 2001 banking crisis has been a turning point for the Turkish economy. After the year 2001, the exchange rate system was transformed from a currency band to a flexible exchange rate system. The Turkish Lira started to appreciate against all reserve currencies and the employment shifted from the agricultural sector to the services sector. These developments increase the relative importance of the "imported input", "labor intensity" and "technology" channels among other transmission channels for the Turkish case.

In the empirical part of this study, a log-linear model was constructed in light of the existing empirical literature. Industrial employment (I-EMP) was explained with five explanatory variables; industrial production index (IPI), producers price index-based real effective exchange rate (REER-PPI), export (X), bank credits to the private sector (BC), and foreign direct investments (FDI). We employed the ARDL bounds testing approach to cointegration methodology and monthly data to investigate the period 2009-M01 to 2019-M10. 
Our empirical findings support a positive and significant relationship between REER-PPI and I-EMP. Accordingly, a $1 \%$ increase in the REER-PPI leads to a $0.092 \%$ increase in I-EMP. This result can be interpreted as the dominance of the "imported input" channel over the other transmission channels for the Turkish industrial sector. The "export" and the "bank credits to private sector" variables have also a significant and positive effect on industrial employment while the impact of the IPI and FDI over the I-EMP is statistically insignificant over this period. This insignificant relationship can be explained by the increasing "capital to labor ratio" in industrial production. Besides the foreign direct investments might be made in less laborsensitive subsectors or these investments could be in the form of real estate purchases of the foreigners which are not related to industrial employment. The last step of the empirical investigation is to test the adequacy of the model through diagnostic tests for stability, heteroscedasticity, normality, and serial correlation. The diagnostic test results prove the adequacy of our model.

The empirical findings of the study are in line with the findings of Filiztekin (2004), Bilgin and Danis (2005), and Dogan and Islam (2018) for the Turkish economy but contradict the findings of Salih and Cengiz (2011) and Boz (2013). This result can be interpreted as a proof for the existence of the aggregation bias since the studies which indicates similar result with our study investigate the relationship at the sectoral base while the investigation of the others is at country-level.

This study suggests that the knowledge about the "country-specific facts" is crucial to construct an adequate model which includes the necessary control variables. Moreover, these specific facts help to interpret the empirical findings of the direction and the strength of the relationship more accurately. The study also finds the aggregation bias as a critical threat for the misinterpretation of the empirical results. Sectoral employment, which makes up total employment, may react in opposite ways to the changes in REER. This may cause us to come to a spurious conclusion about the relationship at the aggregate level since the counter effects may cancel each other. One can conclude no relationship between these two variables despite there are significantly positive and negative relationships between them at the sectoral level. Moreover, analysis over total employment creates some difficulties about the choice of the appropriate REER series since there are different versions like PPI-based, CPI-based, unit-labor cost-based, or sectoral-based REER series. Another suggestion is about the frequency of the data. As the frequency of the data increases, it will be possible to get more accurate results about the time at which the employment level reacts to changes in REER.

The study concludes that the investigation of the relationship will be more definite at the sectoral and sub-sectoral levels. The construction of the sector-specific-REER series and the high frequency of data will help to get more realistic results about the relationship. Since the information about the aggregate response of the employment is more useful for the policymakers, it will be a good idea to measure these responses at the sectoral level and then add them up to get the aggregate response at the country level.

\section{Declarations and Disclosures}

Ethical Responsibilities of Authors: The author of this article confirms that her work complies with the principles of research and publication ethics.

Conflicts of Interest: No potential conflict of interest was reported by the author.

Funding: The author received no financial support for the preparation and/or publication of this article.

Author Contributions: The author confirms sole responsibility for conceptualization and design, data collection, analysis of data and interpretation of results, writing the first draft of the manuscript, and review and editing.

Plagiarism Checking: This article was screened for potential plagiarism using a plagiarism screening program. 


\section{Endnotes}

1. The most known currency crisis existed in Mexico (1994), Turkey (1994), Thailand, Malaysia, Singapore, Indonesia, South Korea (1997), Russia (1998), Brazil (1998-1999) and Argentina (2002).

2. Dooley et al. 2009 have coined the concept "Bretton Woods II" to define a new economic era in which China and other Asian countries became the major players in world economy.

3. The average growth rate of the Turkish economy over the period $1923-2019$ is 5.15\% while the average growth rate is $7.2 \%$ over the period 2002-2007. (Author's own calculation)

4. The trend about the excess funds in the world markets got disrupted in May 2013 when the Fed made "the tapering announcement" to signal about the end of the unconventional monetary policy. (Mishra et al. 2014)

5. Ay and Ayhan (2016), and Usman and Elsalih (2018) use monthly data in their empirical researches.

6. As of 2019, the total exports were 171.4 billion U.S. dollars where the industry sector's exports were 161.6 billion U.S. dollars.

\section{References}

Akarsu, G. (2020). Unemployment, exchange rate and exchange rate volatility relation: Analysis for Turkey. Çankırı Karatekin Üniversitesi Iktisadi ve Idari Bilimler Fakültesi Dergisi, 10(1), 179-209.

Alexandre, F., Bação P., Cerejeria, J., \& Portela, M. (2011). Employment and exchange rates: The role of openness and technology. Open Economies Review, 22(5), 969-984.

Alexandre, F., Baçao, P., Cerejeira, J., \& Portela, M. (2017). Exchange rates, employment and labour market rigidity. The World Economy, 40(5), 993-1011.

Ay, A., \& Ayhan, F. (2016). Employment and exchange rate volatility relationship: The Turkish case. Journal of Business Economics and Finance, 5(1), 108-114.

Bahmani-Oskooee, M., Mirzaie, I. A., \& Miteza, I. (2007). Sectoral employment, wages and the exchange rate: Evidence from the US. Eastern Economic Journal, 33(1), 125-136.

Bakhshi, Z., \& Ebrahimi, M. (2016). The effect of real exchange rate on unemployment. Marketing and Branding Research, 3, 4-13.

Bilgin, M. H., \& Danis, H. (2005). The relationship between employment and real exchange rate: The case of Turkish apparel industry. International Business \& Economics Research Journal (IBER), 4(11), 11-20.

Bernanke, B. (2005). The global saving glut and the U.S. current account deficit. Retrieved January 24, 2021, from https://www.federalreserve.gov/boarddocs/speeches/2005/200503 102/

Bordo, M. D. (1993). A retrospective on the Bretton Woods system: Lessons for international monetary reform. In M. D. Bordo \& B. Eichengreen (Ed.), The Bretton Woods international monetary system: A historical overview (pp. 3108). University of Chicago Press.

Branson, W. H., \& Love, J. P. (1988). The real exchange rate, employment, and output in manufacturing in the US and Japan. National Bureau of Economic Research, No. w2491.

Bredenkamp, H., Josefsson, M., Lindgren, C. J., \& Serdengeçti, S. (2009). Turkey's renaissance: From banking crisis to economic revival. In E. Brau \& I. McDonald (Ed.), Successes of the International Monetary Fund (pp. 64-84). London: Palgrave Macmillan.

Burgess, S. M., \& Knetter, M. M. (1998). An international comparison of employment adjustment to exchange rate fluctuations. Review of International Economics, 6 (1), 151-163.

Campa, J. M., \& Goldberg, L.S. (2001). Employment versus wage adjustment and the US dollar. Review of Economics and Statistics, 83(3), 477-489.

Chipeta, C., Meyer, D. F., \& Muzindutsi, P. F. (2017). The effect of exchange rate movements and economic growth on job creation. Studia Universitatis Babes-Bolyai Oeconomica, 62(2), 20-41.

Çiğdem, B. O. Z. (2013). Türkiye'de reel döviz kuru ve işsizlik ilişkisi: 2003-2012. Marmara Üniversitesi iktisadi ve Idari Bilimler Dergisi, 34(1), 51-61.

Dao, M., \& Chen, R. (2011). The real exchange rate and employment in China. International Monetary Fund, No. 11-148.

Dekle, R. (1998). The Yen and Japanese manufacturing employment. Journal of International Money and Finance, 17(5), 785-801. 
Demir, F. (2010). Exchange rate volatility and employment growth in developing countries: Evidence from Turkey. World Development, 38(8), 1127-1140.

Dogan, E., Islam, M. Q., \& Yazici, M. (2018). Real exchange rates and job flows: Evidence from Turkey. Applied Economics, 50(42), 4489-4499.

Dooley, M., Folkerts-Landau, D., \& Garber, P. (2009). Bretton Woods II still defines the international monetary system. Pacific Economic Review, 14(3), 297-311.

Faria, J. R., \& León-Ledesma, M. A. (2005). Real exchange rate and employment performance in an open economy. Research in Economics, 59(1), 67-80.

Filiztekin, A. (2004). Exchange rates and employment in Turkish manufacturing. Sabanci University, Working Paper.

Frenkel, R., \& Ros, J. (2006). Unemployment and the real exchange rate in Latin America. World Development, 34 (4), 631-646.

Glick, R., \& Hutchinson M. (1990). Does exchange rate appreciation 'deindustrialize' the open economy? A critique of US evidence. Economic Inquiry, 28(1), 19-37.

Gourinchas, P. O. (1999). Exchange rates do matter: French job reallocation and exchange rate turbulence, 1984-1992. European Economic Review, 43(7), 1279-1316.

Hua, P. (2007). Real exchange rate and manufacturing employment in China. China Economic Review, 18(3), 335-353.

Huang, H., Pang, K., \& Tang, Y. (2014). Effects of exchange rates on employment in Canada. Canadian Public Policy, 40(4), 339-352.

Kandil, M., \& Mirzaie, I.A. (2003). The effects of dollar appreciation on sectoral labor market adjustments: Theory and evidence. The Quarterly Review of Economics and Finance, 43(1), 89-117.

Lysenko, D. (2019). The long-run effects of the real exchange rate on employment and wages in Canadian manufacturing. International Review of Applied Economics, 33(4), 477-504.

Mishra, M. P., Moriyama, M. K., N'Diaye, P. M. B., \& Nguyen, L. (2014). Impact of Fed tapering announcements on emerging markets. International Monetary Fund.

Mpofu, T. R. (2013). Real exchange rate volatility and employment growth in South Africa: The case of manufacturing. ECCE-USB Conference Papers.

Mundell, R. (1961). Flexible exchange rates and employment policy. The Canadian Journal of Economics and Political Science, 27(4), 509-517.

Ngandu, S. (2008). Exchange rates and employment. South African Journal of Economics, 76, 205-221.

Nyahokwe, O., \& Ncwadi, R. (2013). Impact of exchange rate volatility on unemployment in South Africa. Mediterranean Journal of Social Sciences, 4(3), 109-109.

Obstfeld, M., \& Rogoff, K. (2009). Global imbalances and the financial crisis: products of common causes. CEPR Discussion Paper No. DP7606.

Peláez S, J. T., \& Sierra S, L. P. (2016). Does industrial employment react to movements in the real exchange rate?: An empirical analysis for Colombia, 2000-2010. Latin American Journal of Economics, 53(1), 39-60.

Peseran, M. H., \& Shin, Y. (1999). An autoregressive distributed-lag modelling approach to cointegration analysis. Econometric Society Monographs, 31, 371-413.

Peseran, M. H., Shin, Y., \& Smith, R. J. (2001). Bounds testing approaches to the analysis of level relationships. Journal of Applied Econometrics, 16(3), 289-326.

Revenga, A. L. (1992). Exporting jobs? The impact of import competition on employment and wages in US manufacturing. The Quarterly Journal of Economics, 107(1), 255-284.

Sahin, A., \& Cengiz, S. (2011). The real exchange rate and the employment market: Evidence for Turkey by panel cointegration analysis. African Journal of Business Management, 5(14), 5845-5854.

Usman, O., \& Elsalih, O. M. (2018). Testing the effects of real exchange rate pass-through to unemployment in Brazil. Economies, 6(3), 49.

Zeng, X., Yuxue, C., Shisong, Q., \& Yumei, Y. (2011). Real exchange rate, foreign trade and employment: Evidence from China. Discussion paper series // Forschungsinstitut zur Zukunft der Arbeit, No. 5931

Zmami, M., \& Ben-Salha, O. (2015). Exchange rate movements and manufacturing employment in Tunisia: Do different categories of firms react similarly? Economic Change and Restructuring, 48(2), 137-167. 
This Page Intentionally Left Blank 